\title{
Toc H Special Committee of B.E.L.R.A.
}

As the result of a visit to Nigeria in 1933, The Rev. P. B. Clayton, (Tubby of Toc $\mathrm{H}$ ) called for volunteers from Toc $\mathrm{H}$ who would be willing to serve in the field for five years or the duration, working to help doctors and especially to build up social welfare work for lepers. The work of Dr. MacDonald of Itu, Southern Nigeria, was their example of what could be done and in addition there was the vast field of preventive work which is likely to be the most fertile in the near future.

One man, Herbert Spencer, is working at Dichpali in H.E.H. The Nizam's Dominions, India, and five others are already in Nigeria.

Hamish MacGregor, Itu.

Len Parker, Onitsha.

Peter Pedrick, Maidugari.

Norman Crayford, Katsina.

William Lambert, Sumali near Kano.

In addition, Dr. Money has reached Nigeria to be in control of the new work at Onitsha.

This pioneer work in Nigeria is under the Direction of Sir Walter Johnson, Director of Medical and Sanitary Service, and the reports of the first tour will be received with great interest by the Special Committee of B.E.L.R.A. -Toc $\mathrm{H}$. 